\title{
Problems of physical activity in vocational training of future teachers
}

\author{
Pakhalchuk N.O. ${ }^{\mathrm{ABCDE}}$, Holyuk O.A. ${ }^{\mathrm{BCDE}}$ \\ Department of Preschool and Primary Education, \\ Mykhailo Kotsyubynskyi Vinnitsa State Pedagogical University, Ukraine
}

Authors' Contribution: A - Study design; B - Data collection; C - Statistical analysis; D - Manuscript Preparation; E - Funds Collection.

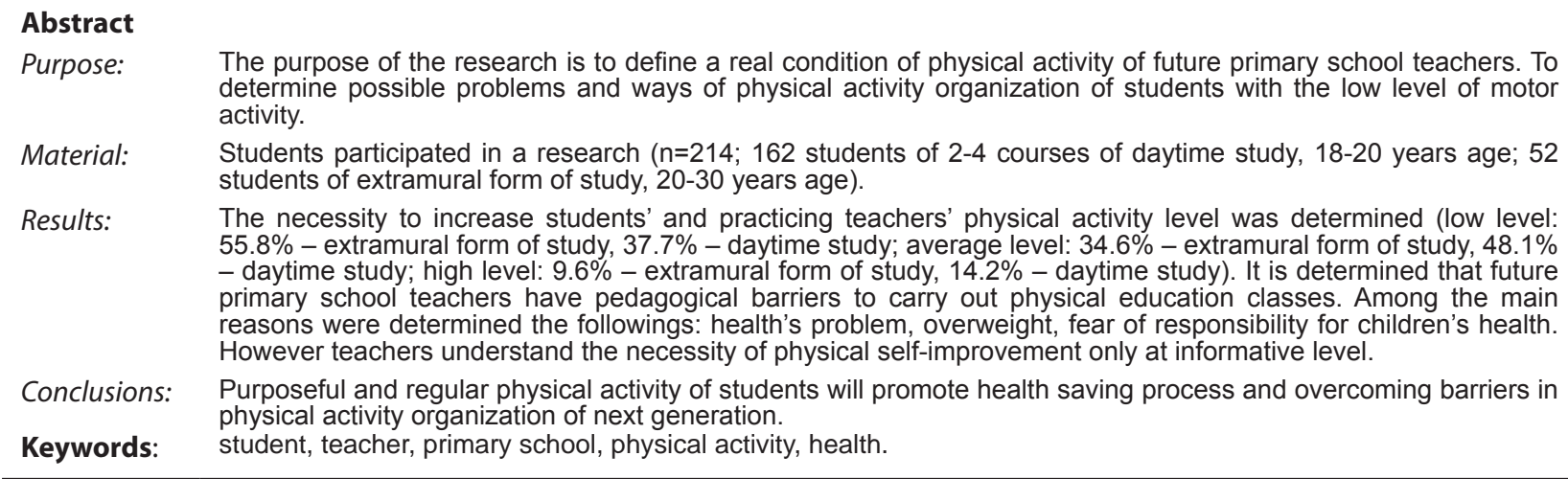

\section{Introduction}

Upbringing of healthy next generation is a priority task of each country. Scientists study features of judo athletes attitude to sports activity [1]; influence of study style at motivation formation in physical training [2]; training process of 6-7 years climbers at the initial stage of preparation with application of the main motor actions and complete method [3]; use of health and fitness technologies at the work with preschool children [4]; introduction of Bothmer Gymnastics to form ability of a rhythm reconstruction [5].

However these problems are unresolved without training of qualified personnel. Now scientists search biomedical, psychological and pedagogical instruments to create health saving and health forming educational environment for students and pupils. Scientists offer the following:

- to use exercises from hatha yoga for students at physical education classes as means of somatic health and physical activity improvement of the personality [6];

- to apply physical training programs, sports-oriented approach to training of functional force $[7,8]$;

- strengthening of strategy of study using assessment for learning (AFL) [9];

- to form goals for achievement and to encourage students to physical training exercises [10, 11];

- to use potential opportunities of all components of health saving technology (axiological, gnosiological, health saving, emotionally volitional, ecological, health and fitness) $[12,13]$;

- to form a healthy lifestyle and to change approaches to carry out physical education classes in educational establishment [14, 15];

- to compensate intellectual and mental loads by optimum physical activity [16, 17];

(C) Pakhalchuk N.O., Holyuk O.A., 2018

doi:10.15561/20755279.2018.0107
- to use Bothmer Gymnastics as "spatial dynamics" which is intended to improve person's physical and mental balance [18].

High-quality training of specialists provides first of all improvement of quality and efficiency of study process in higher educational establishments [19, 20]. The scientists carry out comparison of physical education organization features by experts in the field of physical training and by primary school teachers [21]. It is investigated the problem of physical education teachers' attitude to modern trends and techniques of physical training formation [22], their understanding of educational value of the motor activity and ways of motor skills development [23].

The primary school teachers could have difficulties at physical education classes: misunderstanding of all opportunities for motor skills development of children, lack of experience of the organization of out-of-school physical activity of the personality [24]; limited time for preparation in educational establishment for pupils' physical training [25]. The primary school teachers could improve quality of physical education study at primary school with sports-oriented preparation in educational establishment and by means of experts [26].

Also there are active researches of training system improvement of future experts and professionalism of the practicing primary school teachers according to the following directions:

- strengthening of interrelation between the pedagogical theory and practice of pupils physical education formation [27, 28];

- increase in prestige value and importance of physical education class among teachers, formations of humanistic values [26];

- formation of experience of health and fitness activity in educational establishment, involvement of students into traditional forms of physical education and to wide 
range of motor actions [29];

- development of postdegree programs of teachers' education [30];

- creation of prerequisites for self-education of experts [31].

Scientists proved close connection between indicators of intellectual working capacity, physical state and physical activity [20]. Researchers distinguish the high level of functionality of students among indispensable conditions of educational process' efficiency. This concept means sufficient mental and physical working capacity $[32,33]$. People with appropriate motivation on self-education in the field of physical training will be physically active during lifetime. The internal motivation could become a key to achievement of the goals in education, especially in the field of physical training [34].

Group of scientists studied categories of intentions of future primary school teachers concerning physical education study at school and their ability to overcome barriers in the organization of physical activity (absence of space, lack of the equipment, bad weather, diffidence and so forth) [25]. In our opinion, physical activity has to become important humanistic value. It will promote high performance of the personality. Physical activity of students consists of motor actions which is necessary condition of activity and increase in working capacity [35]. Iermakova T.S. studied experience of formation of students' culture health in Poland and feature of ensuring their physical activity. The scientist conducted research of values of future primary school teachers. Among important priorities Ukrainian students defined the followings:

- necessity of health improvement;

- increase in knowledge of concrete humanity subjects;

- promotion of healthy lifestyle [36, 37].

Malinauskas R. also emphasizes importance of concrete values for sport experts. Values characterize behavior of people and promote development of personality. Humanistic values are important (health, physical development and human communication) [38].

Scientists determined contradictions which appear in the course of physical condition improving of population:

- between demand in highly qualified specialists with excellent health and lack of technologies to decrease the number of students with health problems [39];

- between theoretical researches in the field of healthimproving technologies and their insufficient use in study process at educational establishments [39];

- between necessity to get considerable volume of information by students and lack of time [32];

- between gradual, long-term process of future expert formation and desire of self-realization as soon as possible [32].

It is relevant to determine contradiction between necessity of health saving, activization of students' physical activity and insufficient covering and developing of appropriate technologies and techniques of training.

The analysis of scientific literature covered necessity to organize person's moderate physical activity as 30-60 minutes per day [11]. Ukrainian scientists determined that such indicator for students has to be 12-14 hours per week at sufficient physiologic load [35]. Therefore it is possible to assume that organization of physical activity of future primary school teachers of non sports subjects will influence on: health improvement of future teachers; positive attitude to physical education classes at primary school.

The purpose of the research is to define a real condition of physical activity of future primary school teachers.

The task of the research is to determine possible problems and ways of physical activity organization of students at classes with the low level of motor activity.

\section{Material and methods}

Participants: students $(\mathrm{n}=214)$ getting bachelor degree on specialty «Primary education» at Vinnytsia State Pedagogical University named after Mykhaylo Kotsiubynsky (Ukraine) participated in a research. Participants were students of 2-4 courses of daytime study ( $\mathrm{n}=162$, age - from 18 to 20 years) and students of extramural form of study ( $\mathrm{n}=52$, age - from 20 to 30 years, have 1-6 years of work experience as primary school teacher) who entered the university on the basis of qualification level "Junior specialist".

Organization of research: study of physical activity level was carried out with the help of technique of Fleming research. It is allowed to define quantitative and qualitative daily physical activity of students. The different daily activity is at the bottom of such chronometry [40]. Each participant of experiment carried out the fixing of physical activity exercises with different intensity and fixing of performance time. Data was registered into special form. All physical activity of the person is divided into five levels. Each level is corresponded to the certain types of physical activity:

- basic (sleep, relax);

- in sitting position (watching tv, reading, preparation for study at education establishments, driving, board and computer games, eating and so forth);

- small (personal hygiene, condition with low mobility, study at education establishment, using transport, walking);

- average (housekeeping, walks, morning exercises);

- high (participation in specially organized physical training classes, dances, intensive games, run, skating, rollers, bicycle and so forth) [41].

Use of weighing coefficients different by intensity of physical activity types gave the opportunity for each respondent to define quantitative value of students' daily physical activity index $\left(\mathrm{I}_{\mathrm{PA}}\right)$.

The attitude of students to problems of teachers' and children' physical activity of primary school was studied by means of specially developed questionnaire. It consisted of questions of essence of a healthy lifestyle and its components; influence of sports and physical exercises on health and efficiency of the teacher and child. Students expressed own position relatively: reasons of sedentary lifestyle of the modern person; role of the teacher in a physical development of child; dependence of physical 
culture development level of pupils on physical activity of the teacher.

All students were participated as volunteers and gave the written consent to participate in a research on condition of anonymity. Before the beginning of experiment students were briefed on the purpose of research and on the possibility to finish the participation in any time without explanation.

Statistical analysis: it was used the method of transformation of empirical data of poll into quantitative indices. The students' daily physical activity index $\left(\mathrm{I}_{\mathrm{PA}}\right)$ was counted by formula 1. The basic level of physical activity corresponds to weighing coefficient $\mathrm{k}$ which is 1,0 ; to sedentary $-\mathrm{k}=1,1$; to small $-\mathrm{k}=1,5$; to average $\mathrm{k}=2,4$; to high $-\mathrm{k}=5,0$ [42].

$$
\mathrm{I}_{P A}=\sum_{\mathrm{n}=1}^{\mathrm{m}} \mathrm{t}_{\mathrm{m}} \times \mathrm{k},
$$

where $\mathrm{m}$ - is the number of notes in the registration form, each of them correspond to certain type of activity, $\mathrm{t}_{\mathrm{m}}$ - is the time spent on it, $\mathrm{k}-$ is the weighing coefficient of appropriate level of student's physical activity.

The obtained data were processed by means of Microsoft Excel.

For data processing of questionnaire was carried out the scale - improvement of initial empirical data by their transfer to scales indices, percentage frequencies.

\section{Results}

According to the numerical values of physical activity indexes all students were divided into three groups by levels of physical activity: low $\left(\mathrm{I}_{\mathrm{PA}}<31\right.$ point), average $\left(31 \leq \mathrm{I}_{\mathrm{PA}} \leq 34\right)$, high ( $\mathrm{I}_{\mathrm{PA}}>34$ points).

Results of research testified domination of average and low levels of physical activity of «Primary education» specialty students (fig. 1). The comparative analysis of the obtained data demonstrated that quality of students' physical activity of extramural form of study is much lower in comparison with students of daytime study. It is revealed that most of respondents $(91,4 \%)$ is not satisfied with the own level of physical activity. They understand its value for own health, but consciously prefer intellectual activity.

Students of daytime study (76,5\%) chose lack of time for independent work of all study subject as the reason of sedentary lifestyle. Students with the high level of study progress note that thorough preparation causes threefour hours sleep per day. According to the results of poll students with high level of physical activity consciously chose a priority of physical self-improvement over the academic progress in study.

Students of daytime $(98,8 \%)$ and extramural form of study (100\%) chose physical culture and physical culture with prerequisites among subject with physical activity. According to students' point of view, teachers of other subjects paid no attention to the organization of physical activity. There are only several disciplines where teachers use interactive forms of work with students on laboratory classes.

$51,9 \%$ of daytime and extramural form of study students convince that parents have responsibility for physical development of child. They have to take care of morning exercises, sports sections for the child and active family vacation. They consider own role in educational

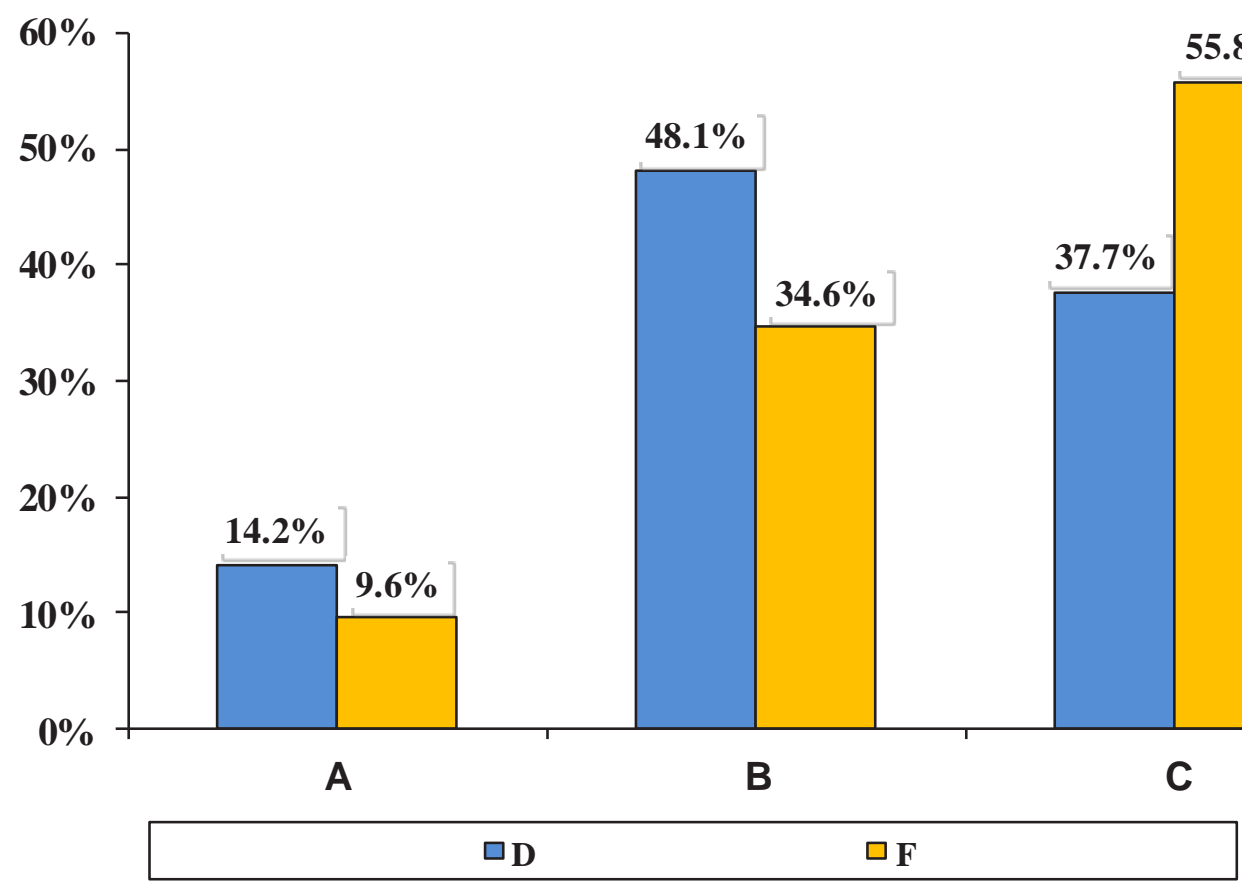

Fig. 1. Percentage distribution of daytime and extramural form of study students by levels of physical activity: A - high level; B - average level; C - low level; D - daytime form of study; F - extramural study form of study. 
work with parents only.

Extramural form of study students $(88,5 \%)$ defined a tendency to decrease in physical activity after graduation from pedagogical colleges. All students of this group work as primary school teachers. It is connected with the fact that all free time after work they spend with family and fill out documentation. People of countryside (78,8\%) consider that housework is the main type of physical activity. This type of activity increases during the spring farm work.

It is determined that future primary school teachers have pedagogical barriers in carrying out physical education class. Among the main reasons were chose the following: health problems, overweight, fear of responsibility for children' health. In this situation teachers understand the necessity of physical self-improvement only at informative level.

Generalization of students' answers results allow to draw a conclusion that modern primary school teachers have insufficient understanding of dependence of pupils' physical culture development level on their physical activity. Not sufficient attention is paid to physical activity breaks during the classes. Rather often teachers have insignificant set of exercises. Physical activity breaks use during all study period of child at primary school. As a result children lose interest and do physical exercises poorly. A lot of teachers consider physical education classes at primary school as an opportunity for child to get rid of excess energy. Plans of educational work of primary school teachers are overloaded with educational conversations on various subjects, in particular concerning physical training. However only physically active teachers prefer organize joint vacation with pupils (hikes, sports competitions, travels, outdoor games and so forth). Teachers do not carried out gymnastics before classes and health hours.

\section{Discussion}

Our researches prove and complete data about features of students' and primary school teachers' physical activity. Thus, in the course of experimental study scientists drew the following conclusions concerning primary school teachers:

- only physically active teachers can effectively form physical culture of children [27];

- teachers have to be encouraged to active life style to form models of physical activity [25];

- it is necessary to consider advanced pedagogical experience in the process of future teachers training [30];

- it is necessary to form students' confidence in own pedagogical knowledge, especially it concerns students who have negative experience of physical education classes at school [43].

Our research:

- pays attention on the problems of physical activity organization of future primary school teachers in the course of academic load;

- confirms necessity to consider influence of physical activity on intellectual efficiency of students depending on specifics of future professional activity [44];

- expands limits of researches which are directed to activization of students' physical activity only at physical education classes.

We analyzed the specialists' curriculum and training programs by specialty «Primary education». All study disciplines (about 50) were divided into levels of motor density:

1. Physical education, sports sections by free choice of students (high level).

2. Physical education with prerequisites (average level).

3. Didactics, introduction to scientific and pedagogical researches, fundamentals of mathematics with teaching technique of educational field "Mathematics", fundamentals of informatics with teaching technique (low level).

The majority of subjects do not provide the active motor activity of students. There is a necessity to search the ways of physical activity activization, to carry out special sports, health and fitness events with students.

For the purpose of students' physical activity activization was offered the following:

1. To use elements of Bothmer Gymnastics. It is also consisted of special rhythmical and breathing exercises which can be carried out in different starting positions (sitting, standing).

2. To carry out kinesiological physical activity breaks for sense of sight, body posture, relax.

3. To coordinate the list of theoretical and practical tasks for independent study. To decrease the list of these tasks and to increase the quality of performance and so forth.

Relevant questions are:

- research of influence of different methods, methods of teaching and students' organization at vocational training classes on the level of their physical activity; - determination of teachers' physical activity level; influence of teachers' active lifestyle on the formation of students' motivation to physical education classes; - proving or disposing of correlation of mental welfare levels of future primary school teachers and physical activity.

\section{Conclusions}

1. The primary school teachers are important persons in the process of pupils' health saving and strengthening.

2. If physical training classes are conducted by experts on specialty «Physical training and sport», then primary school teachers are responsible for the organization of health and fitness events for primary school. It is important component of pupils' physical training formation. Such health and fitness events are physical activity breaks, gymnastics before classes, organized active breaks, health hours and so forth. Therefore physical activity is important factor of teachers' professionalism formation.

3. Values are formed in the social environment. The question of humanistic values' formation at future primary school teachers in the field of physical education and sport 
and physical activity in particular is relevant.

4. The important question is formation of students' motivation to motor activity not only at physical education classes, but also at the all disciplines of professional cycle. Physical training of students in the course of study can be carried out not only at physical education classes and

\section{References}

1. Bliznevsky A, Kudryavtsev M, Kuzmin V, Tolstopyatov I, Ionova $\mathrm{O}$, Yermakova $\mathrm{T}$. Influence of personal characteristics of pupils and students on the effectiveness of the relationship to the specific physical activities. Journal of Physical Education and Sport, 2016; 16(2): 424-432. doi:10.7752/ jpes.2016.02066

2. De Meyer J, Soenens B, Aelterman N, De Bourdeaudhuij I, Haerens L. The different faces of controlling teaching: implications of a distinction between externally and internally controlling teaching for students' motivation in physical education. Physical Education and Sport Pedagogy, 2016; 21(6):632-652. doi:10.1080/17408989.2015.1112777.

3. Kozina Z, Repko O, Kozin S, Kostyrko A, Yermakova T, Goncharenko V. Motor skills formation technique in 6 to 7-year-old children based on their psychological and physical features (rock climbing as an example). Journal of Physical Education and Sport, 2016; 16(3):866-874. doi:10.7752/ jpes.2016.03137

4. Pakhalchuk N. Pedagogical conditions of activation of children's motional activity. Pedagogichni nauki: teoriia, istoriia, innovacijni tekhnologii, 2016; 7(61): 80-90. (in Ukrainian)

5. Pakhal'chuk N. Education of rhythm feeling at children of senior preschool and primary school age by means of Bothmer Gymnastics. Pedagogichni nauki: teoriia, istoriia, innovacijni tekhnologii, 2015; 7(51): 332-340. (in Ukrainian)

6. Kondakov VL, Kopejkina EN, Balysheva NV, Usatov AN. Hatha-yoga practices to improve physical education process efficiency. Teoriia i praktika fizicheskoj kul tury, 2017; 6:2123. (in Russian)

7. Doroshenko EY, Svatyev AV, Iermakov SS, Jagiełło W. The use of cardio training facilities in training 7-9 year old judo athletes. Archives of Budo Science of Martial Arts and Extreme Sports. 2017;13.

8. Osipov AYu, Kudryavtsev MD, Iermakov SS, Yanova MG, Lepilina TV, Plotnikova II, Dorzhieva OS. Comparative analysis of effectiveness of some students' physical culture training methodic. Physical education of students, 2017; 12 (4):176-181. doi:10.15561/20755279.2017.0405

9. Leirhaug PE. Exploring the relationship between student grades and assessment for learning in Norwegian physical education. European Physical Education Review, 2015; 22(3):298-314.

10.Druz VA, Iermakov SS, Nosko MO, Shesterova LY, Novitskaya NA. The problems of students' physical training individualization. Pedagogics Psychology MedicalBiological Problems of Physical Training and Sports. 2017;21(2):51-59. doi:10.15561/18189172.2017.0201

11. Warburton DE, Nichol CW, Bredin SS. Health benefits of physical activity: the evidence. Canadian Medical Association Journal, 2006; 174:801-809. doi: 10.1503/ cmaj.051351

12.Kriventsova I, Pashkevych S, Iermakov S, Bartík P, Michal J, Nosko M, Yermakova T. Fitness - aerobic training of 15 sports sections. It is necessary to carry out this work at all disciplines of bachelors study.

5. Children and students need creation of health saving and health forming environment.

\section{Conflicts of interest}

The authors declare that there is no conflict of interests.
- 17 years' age girl students, who have significant risk of deviations in backbone functional state. Journal of Human Sport and Exercise, 2017;12(4), 1289-1297. doi:10.14198/ jhse.2017.124.15

13.Nosko MO, Garkusha SV, Voiedilova OM. Health saving technologies in physical education. Kyiv: SPD Chalchinska N.V.; 2014. (in Ukrainian)

14.Ivashchenko OV, Iermakov SS, Khudolii OM, Cretu M., Potop V. Level of physical exercises' mastering in structure of 11-13 yrs age boys' motor fitness. Pedagogics, psychology, medical-biological problems of physical training and sports, 2017; 21(5): 236-243. doi:10.15561/18189172.2017.0506

15.Zavidivs'ka NN. Fundametalization of health and fitness education. Kyiv: UBS NBU; 2012. (in Ukrainian)

16.Ivashchenko OV, Iermakov SS, Khudolii OM. The peculiarities of motor fitness' classification model of 6-10 years old girls. Pedagogics, psychology, medical-biological problems of physical training and sports, 2017; 21(6): 260265. doi:10.15561/18189172.2017.0601

17.Kozina ZhL, Ashanin VS. Harmonious combination of intellectual and physical development as necessary condition of students' health improving and training of qualified specialists. Fizicheskoe vospitanie studentov tvorcheskikh special'nostej, 2007;1:152-156. (in Russian)

18.Pakhal'chuk N. Use of pedagogical technologies in training of specialists of preschool and primary education to physical training of children. In: Technologies of Shaping and Enhancing Health of Human and Society. Opole: The Academy of Management and Administration in Opole; 2016. P. 171-177. (in Ukrainian)

19.Jagiełło M, Iermakov SS, Nowiński M. Differentiation of the somatic composition of students physical education specialising in various sports. Archives of Budo Science of Martial Arts and Extreme Sports. 2017;13.

20.Tishchenko VA. Influence of students' physical development on their professional teaching. Physical Education of Students, 2012; 2:96-99.

21.De Corby K, Halas J, Dixon S, Wintrup L, Janzen H. Classroom teachers and the challenges of delivering quality physical education. The Journal of Education Research, 2005; 98(4):208-220. doi:10.3200/JOER.98.4.208-221

22.Sobianin FI, Pakhomova LE, Petrenko OV, Nikolaeva ES. Attitudes of physical education teachers to modern physical education trends. Teoriia i praktika fizicheskoj kul'tury, 2017; 6:9-11. (in Russian)

23.Larsson H, Nyberg G. “It Doesn't Matter How They Move Really, as Long as They Move”. Physical Education Teachers on Developing Their Students' Movement Capabilities. Physical Education and Sport Pedagogy, 2017; 22(2):137149.

24.Faulkner G, Dwyer J, Irving H. Specialist or Nonspecialist Physical Education Teachers in Ontario Elementary Schools: Examining Differences in Opportunities for Physical Activity. The Alberta Journal of Educational Research, 2008; 54(4): 407-419. 
25.Faulkner G, Reeves C, Chedzoy S. Nonspecialist, preservice primary-school teachers: Predicting intentions to teach physical education. Journal of Teaching in Physical Education, 2004; 23:200-215. doi: 10.11.23/jtpe.23.3.200

26.Morgan PJ, Hansen V. Recommendations to improve primary school physical education: classroom teachers' perspective. The Journal of Education Research, 2007; 101(2):99-111. doi:10.3200/JOER.101.2.99-112

27.Chróinín D, O’Sullivan M. Elementary Classroom Teachers' Beliefs across Time: Learning to Teach Physical Education. Journal of Teaching in Physical Education, 2016; 35(2):97106. doi:10.1123/jtpe.2015-0030

28.Khudolii OM, Ivashchenko OV, Iermakov SS, Rumba OG. Computer simulation of Junior gymnasts' training process. Science of Gymnastics Journal, 2016;8(3):215-228.

29.Garrett R, Wrench A. Physical experiences: Primary student teachers' conceptions of sport and physical education. Physical Education and Sport Pedagogy, 2007; 12(1):23-42. doi:10/1080/17408980601060234

30.Fletcher T, Mandigo J, Kosnik C. Elementary Classroom Teachers and Physical Education: Change in Teacher-Related Factors during Pre-Service Teacher Education. Physical Education and Sport Pedagogy, 2013; 18(2):169-183. doi: 10.1080/17408989.2011.649723

31.Petrie K. Creating Confident, Motivated Teachers of Physical Education in Primary Schools. European Physical Education Review, 2010; 16(1):47-64. doi:10.1177/1356336X10369200

32.Podrigalo I, Iermakov S, Rovnaya O, Zukow W, Nosko M. Peculiar features between the studied indicators of the dynamic and interconnections of mental workability of students. Journal of Physical Education and Sport, 2016; 16(4):1211-1218. doi:10.7752/jpes.2016.04193

33.Szumilewicz A, Worska A, Piernicka M, Kuchta A, Kortas J, Jastrzwbski Z, et al. The Exercise-Induced Irisin Is Associated with Improved Levels of Glucose Homeostasis Markers in Pregnant Women Participating in 8-Week Prenatal Group Fitness Program: A Pilot Study. Biomed Research International. 2017. doi:10.1155/2017/9414525

34.Ardeńska A, Tomik R, Berber S. A comparison of physical education students' motivation using the Polish and Turkish versions of the academic motivation scale. Journal of Human Kinetics, 2016; 54(1):207-218. doi:10.1515/ hukin-2016-0046
35.Griban GP. Life activity and motor activity of students. Zhytomyr: Ruta; 2009. (in Ukrainian)

36.Iermakova TS. Forming a health culture of future teachers in Polish educational establishments. Physical Education of Students, 2014; 18(5):14-19. doi:10.15561/20755279.2014. 0503

37.Ivashchenko OV, Yermakova TS. Structural model of in-group dynamic of 6-10 years old boys' motor fitness. Pedagogics Psychology Medical-Biological Problems of Physical Training and Sports. 2015;19(10):24-32. doi:10.15561/18189172.2015.1004

38.Malinauskas R. Dynamics of values held by future sport teachers: a longitudinal study. South African for Research in Sport, Physacal Education and Recreation, 2015; 37(1):7786.

39.Skurikhina NV, Kudryavtsev MD, Kuzmin VA, Iermakov SS. Fitness yoga as modern technology of special health groups' girl students' psycho-physical condition and psychosocial health strengthening. Physical Education of Students, 2016; 20(2): 24-31. doi:10.15561/20755279.2016.0204

40.Davidenko E, Masaud R. Technique of Fleming research of person' physical activity: recommendations. Kiev: Olympic Literature; 1999. (in Russian)

41.Krucevich TIu, Vorobjov MI, Bezverkhnia GV. Control in physical education of children, teenagers and youth. Kiev: Olympic Literature; 2011. (in Ukrainian)

42. Yadviga YuP, Korobeinikov GV, Petrov GS, Koval' $\mathrm{SB}$, Dudnik OK. Influence of motive activity on the psychological emotional consisting of students of institute of higher of economic specialities of modern terms of teaching. Pedagogics, Psychology, medical-biological problems of physical training and sports, 2009; 12: 202-204.

43.Morgan P, Bourke S. Non-Specialist Teachers' Confidence to Teach PE: The Nature and Influence of Personal School Experiences in PE. Physical Education and Sport Pedagogy, 2008; 13(1): 1-29. doi:10.1080/17408980701345550

44.Korobejnikov GV. Psychophysiological organization of person's activity. White Church: BNAU; 2008. (in Russian)

Information about the authors:

Pakhalchuk N.O. (Corresponding author); http://orcid.org/0000-0001-7098-3821; pahalchukn@gmail.com; Department of Preschool and Primary Education, Mykhailo Kotsyubynskyi Vinnitsa State Pedagogical University; 32 Ostrozkiy str., Vinnytsya, 21100, Ukraine.

Holyuk O.A.; http://orcid.org/0000-0001-6309-9261; o.goluk@gmail.com; Department of Preschool and Primary Education, Mykhailo Kotsyubynskyi Vinnitsa State Pedagogical University; 32 Ostrozkiy str., Vinnytsya, 21100, Ukraine.

Cite this article as: Pakhalchuk NO, Holyuk OA. Problems of physical activity in vocational training of future teachers. Physical education of students, 2018;22(1):47-50. doi:10.15561/20755279.2018.0107

The electronic version of this article is the complete one and can be found online at: http://www.sportedu.org.ua/index.php/PES/issue/archive

This is an Open Access article distributed under the terms of the Creative Commons Attribution License, which permits unrestricted use, distribution, and reproduction in any medium, provided the original work is properly cited (http://creativecommons.org/licenses/by/4.0/deed.en).

Received: 15.11.2017

Accepted: 12.12.2017; Published: 27.02.2018 